\title{
STUDY OF RESISTANCE SPOT WELDING BETWEEN AISI 301 STAINLESS STEEL AND AISI 1020 CARBON STEEL DISSIMILAR ALLOYS
}

\author{
M. Ishak, L. H. Shah, I. S. R. Aisha, W. Hafizi and M. R. Islam \\ Faculty of Mechanical Engineering, \\ University Malaysia Pahang \\ 26600 Pekan, Malaysia \\ Tel: 09-4246235; Fax:09-4246222 \\ Email:mahadzir@ump.edu.my
}

\begin{abstract}
Joining dissimilar metals has recently become very popular in industries because of the advantages associated with the weld joint. This paper focuses on an investigation of mechanical and material properties, and the optimization of mechanical properties in resistance spot welding methods in lap configurations between AISI 301 stainless steel and AISI 1020 carbon steel. The Taguchi method was used to design experiments. Welding was conducted using a spot welder. Tensile and Charpy impact test specimens were prepared from the welded sheets in appropriate dimensions and tensile and Charpy impact tests were performed for each specimen. The depth and width of weld nuggets were investigated. It can be concluded from the investigation that the welding joint in this method can offer moderate strength and moderate Charpy impact energy. From the results of the Taguchi analysis, the combination of optimum parameters for dissimilar stainless steel-carbon steel resistance spot welding is: welding current, 5.0kA; welding squeeze time, 3.0 cycle; and welding pressure, 40 psi. In order to improve significant mechanical and metallurgical properties of the joint, other variable parameters like voltage, electrode tip diameter etc. can also be introduced and investigated so that the most influential parameters and their suitable ranges can be identified.
\end{abstract}

Keywords: AISI 301 stainless steel; AISI 1020 carbon steel; RSW; tensile test; Charpy test.

\section{INTRODUCTION}

Resistance spot welding (RSW) is a proficient joining method commonly used for sheet metal joining. RSW has outstanding technical and economic advantages, such as its high speed, suitability for automation and low cost, which make it an attractive choice for the production of auto bodies, truck and rail cabins, home appliances etc. (Aslanlar, Ogur, Ozsarac, \& Ilhan, 2008; Charde, 2012a, 2012b). As a large number of spot welds are applied in each of these particular applications - 3000-7000 in an auto body the variable process parameters in RSW need to be very well adjusted (Martín, López, \& Martín, 2007; Rahman, Arrifin, Nor, \& Abdullah, 2008; Shah, Akhtar, \& Ishak, 2013). Additionally, dissimilar steel sheet structures are more demanding than single steel sheet structures due to spatter generation and electrode contamination issues during welding (Luo, Liu, Xu, Xiong, \& Liu, 2009).

Like any other welding method, joint quality in RSW is directly affected by the variable input parameters. A very common problem is controlling the input parameters 
to obtain a sound welding joint with the required mechanical and metallurgical properties (such as strength and toughness, microstructure etc.) (Farhad \& Mehdi, 2010; Rahman, Rosli, Noor, Sani, \& Julie, 2009). Finding the relationships between the mechanical and metallurgical properties of RSW welding joint and process parameters is thus of great interest in the related industrial applications (Hamidinejad, Kolahan, \& Kokabi, 2012; Rafiqul, Ishak, \& Rahman, 2012; Rahman et al., 2008).

The features and mechanical performance of RSW significantly affect the durability and impact resistance of a vehicle. Dissimilar RSW is more complex than similar welding, due to the different thermal cycles experienced by each metal. Despite the various applications of dissimilar RSW, reports in the literature dealing with mechanical behaviors of RSW joints are limited (Marashi, Pouranvari, Amirabdollahian, Abedi, \& Goodarzi, 2008). RSW is used to join dissimilar metals such as stainless steel and carbon steel because of its flexibility, easy process control and need for simple equipment (Kolarik et al., 2012). Commonly, dissimilar metal welding refers to the joining of metals that have differences in physical, chemical and mechanical properties, such as melting point, thermal conductivity and expansion coefficient, corrosion resistance, strength, hardness, microstructure etc. (Alenius, Pohjanne, Somervuori, \& Hänninen, 2006; Hernandez, Kuntz, Khan, \& Zhou, 2008; Marashi et al., 2008). AISI 301 stainless steel and AISI 1020 carbon steel were used in this study because this stainless steel has good corrosion resistance as a result of its chromium content. AISI 301 stainless steel is widely used to produce screw, machine parts and chemical equipment. AISI 1020 carbon steel was selected because of its hardness $(140 \mathrm{HV})$ which is lower than that of AISI 301 stainless steel (240 HV). AISI 301 stainless steel is widely used for bolts, nuts, sheet material and machine components (Serope \& Steven, 2000). In this paper, RSW was used to join the dissimilar metals of AISI 301 stainless steel and AISI 1020 carbon steel. "Welding Current", "Welding Squeeze Time" and "Welding Pressure" were the variable process parameters. The weldability of AISI 301 stainless steel and AISI 1020 carbon steel was investigated through tensile and Charpy impact tests. A distinct type of compound formed by joining two or more different materials and which has different properties from those of the parent materials, is called an intermetallic compound, IMC (Imaizumi, 1984). IMCs cause defects such as cracks, and deteriorate the mechanical properties of joints due to their brittle nature and so IMC formation was also investigated. Taguchi analysis was implemented to determine the significance and effects of variable parameters on response so that a variable parameter range can be identified in order to improve significant mechanical properties of the joint. The responses were optimized by determining the variable parameters through fine tuning, and confirmation tests for optimization were performed for validation.

\section{EXPERIMENTAL METHOD}

The materials used in this work were AISI 301 stainless steel and AISI 1020 carbon steel sheets. Prior to experimentation, pre-tests were conducted to determine the minimum and maximum anticipated welding current, welding squeeze time and welding pressure. The chemical compositions of the base materials are shown in Table 1. 
Table 1. Chemical composition of base materials [wt\%].

\begin{tabular}{cccccccccc}
\hline \multicolumn{1}{c}{ Element \% } & $\mathrm{Fe}$ & $\mathrm{C}$ & $\mathrm{Si}$ & $\mathrm{Mn}$ & $\mathrm{Cr}$ & $\mathrm{Mo}$ & $\mathrm{Ni}$ & $\mathrm{Co}$ & $\mathrm{Cu}$ \\
\hline AISI 301steel & 71.5 & 0.0617 & 0.473 & 1.36 & 17.1 & 0.0888 & 8.39 & 0.149 & 0.601 \\
AISI 1020 steel & 99.5 & 0.0910 & 0.005 & 0.196 & 0.0493 & 0.0158 & 0.0371 & 0.001 & 0.001 \\
\hline
\end{tabular}

The pre-tests were conducted to find the parameters that would form a structurally sound weld, and so maximum, middle and minimum values for each parameter were determined. As shown in Table 2, parameter level selection was made by analyzing Figure 1 and Figure 2. Based on the Taguchi analysis, an L9 orthogonal array was used to determine the total number of experiments, as shown in Table 3 . The experiments were labelled A to I. The welding operation was conducted using a spot welding machine.

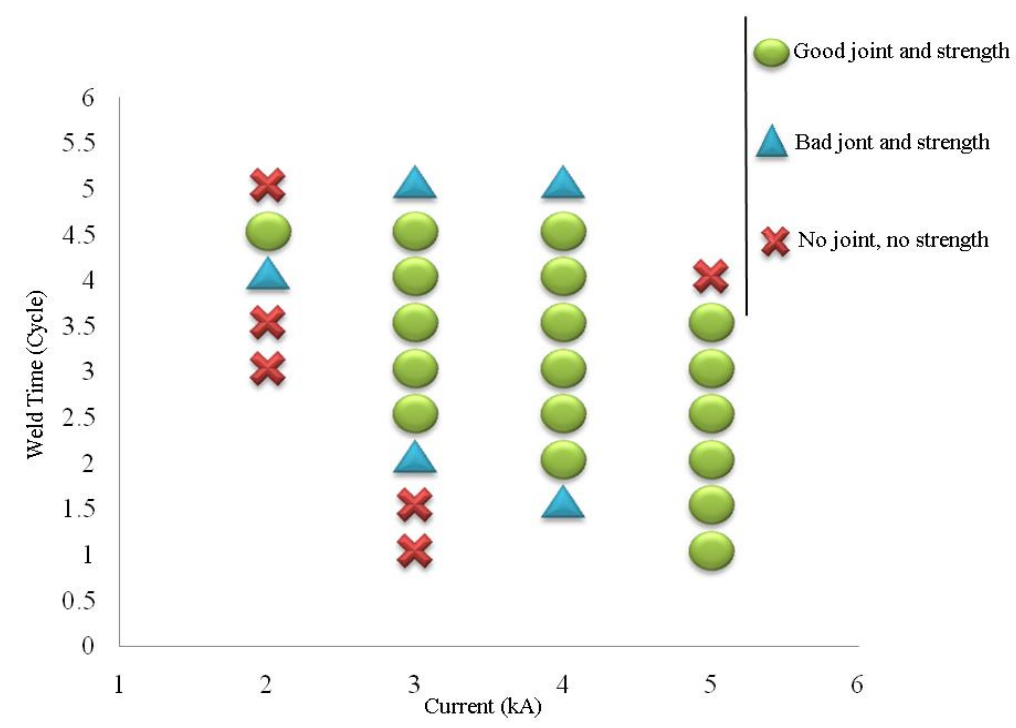

Figure 1. Pre-test experiments (Welding current vs. Welding squeeze time)

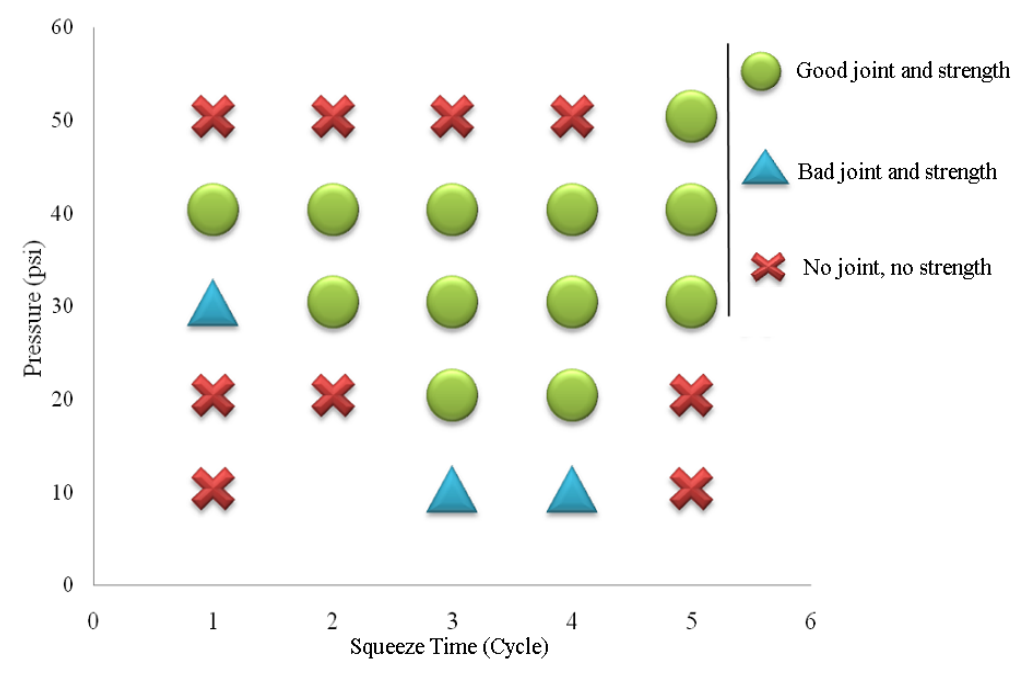

Figure 2. Graphs for pre-test experiments (Welding squeeze time vs. welding pressure) 
Table 2. Parameter selection and levels.

\begin{tabular}{ccc}
\hline Parameter & Level & Value \\
\hline \multirow{3}{*}{ Welding Current [kA] } & 1 & 3.0 \\
& 2 & 4.0 \\
& 3 & 5.0 \\
\hline \multirow{2}{*}{ Welding Squeeze Time (cycle) } & 1 & 2.5 \\
& 2 & 3.0 \\
& 3 & 3.5 \\
\hline \multirow{2}{*}{ Welding Pressure (Mpa) } & 1 & $0.21(30 \mathrm{psi})$ \\
& 2 & $0.24(35 \mathrm{psi})$ \\
& 3 & $0.28(40 \mathrm{psi})$ \\
\hline
\end{tabular}

After the welding process was completed, the mechanical properties of the joints were tested using tensile and Charpy impact tests. In the material laboratory, a Shimadzu tensile tester was used to obtain the tensile and yield strengths. Each experiment was repeated three times. The results were recorded for each test, and the average values were taken for each test. A digital Charpy impact tester was used to determine the value of the Charpy impact energy. The Charpy impact energy is the energy absorbed when the work piece fractures. Each experiment was repeated three times, and the Charpy impact energy values were recorded for each test. To perform the Taguchi analysis, the results from the tensile and Charpy impact tests were analyzed, and analysis of variance (Fonseca, Casanova, \& Valdés) was used to identify the most influential parameters and the level of effects on the responses. Regression analysis was also conducted to generate a model for the tensile strength and Charpy impact energy. The experimental results and the results from the derived model were compared to verify and validate the experiments. A macro-structural analysis of the weld joint was conducted, using an optical microscope. The weld nugget's width and depth was measured for each specimen.

Table 3: Design of experiments (L9 Orthogonal Array).

\begin{tabular}{cccc}
\hline $\begin{array}{c}\text { No. Of } \\
\text { Experiments }\end{array}$ & $\begin{array}{c}\text { Current } \\
{[\mathrm{kA}] \mathrm{A}}\end{array}$ & $\begin{array}{c}\text { Welding Squeeze Time } \\
\text { [cycle] B }\end{array}$ & $\begin{array}{c}\text { Welding pressure } \\
{[\mathrm{MPa}] \mathrm{C}}\end{array}$ \\
\hline A & 1 & 1 & 1 \\
B & 1 & 2 & 2 \\
C & 1 & 3 & 3 \\
D & 2 & 1 & 2 \\
E & 2 & 2 & 3 \\
F & 2 & 3 & 1 \\
G & 3 & 1 & 3 \\
H & 3 & 2 & 1 \\
I & 3 & 3 & 2 \\
\hline
\end{tabular}




\section{RESULTS AND DISCUSSION}

\section{Tensile Testing}

A tensile test was performed three times for each specimen and the average values were taken as shown in Table 4. From Table 4, we can see that Joint $\mathrm{H}$ exhibited the highest tensile strength of $200.71 \mathrm{MPa}$. The tensile strength of AISI 301 stainless steel and AISI 1020 carbon steel base metals was $520 \mathrm{MPa}$ and $379.00 \mathrm{MPa}$ respectively. The joint efficiency for joint $\mathrm{H}$ compared to AISI 1020 carbon steel base metal was thus $52.96 \%$. The lowest tensile strength of $66.43 \mathrm{MPa}$ was achieved for joint A with very low joint efficiency of $17.53 \%$ compared to AISI 1020 carbon steel base metal. Joint H exhibited the maximum yield strength of $140.00 \mathrm{MPa}$ and joint $\mathrm{A}$ exhibited the lowest yield strength which is $62.33 \mathrm{MPa}$. The yield strength of AISI 301 stainless steel and AISI 1020 carbon steel base metal is $206 \mathrm{MPa}$ and $205 \mathrm{MPa}$ respectively. The joint efficiency compared to yield strength of AISI 1020 carbon steel for joint $\mathrm{H}$ and A was $68.28 \%$ and $30.41 \%$ respectively. 5 out of 9 joints achieved more than $50 \%$ of the yield strength of AISI 1020 carbon steel base metal. So, in Table 4, from the joint efficiency values in terms of both tensile and yield strength of AISI 1020 carbon steel, it can be concluded that a moderate strength of joints was achieved.

Table 4. Tensile test data (force, displacement, tensile strength, strain and yield strength).

\begin{tabular}{cccccccc}
\hline Experiment & $\begin{array}{c}\text { Force } \\
(\mathrm{N})\end{array}$ & $\begin{array}{c}\text { Displacement } \\
(\mathrm{mm})\end{array}$ & $\begin{array}{c}\text { Tensile } \\
\text { Strength, } \\
\text { TS (MPa) }\end{array}$ & $\begin{array}{c}\text { Joint } \\
\text { Efficiency } \\
\text { in of TS } \\
\text { of AISI } \\
1020\end{array}$ & $\begin{array}{c}\text { Strain } \\
(\%)\end{array}$ & $\begin{array}{c}\text { Yield } \\
\text { Strength, } \\
\text { YS } \\
(\mathrm{MPa})\end{array}$ & $\begin{array}{c}\text { Joint } \\
\text { Efficiency } \\
\text { in of YS } \\
\text { of AISI } \\
1020\end{array}$ \\
\hline A & 4650.29 & 0.41007 & 66.43 & 17.53 & 0.45563 & 62.33 & 30.41 \\
B & 6052.80 & 0.62029 & 86.47 & 22.82 & 0.68921 & 82.00 & 40.00 \\
C & 6942.88 & 0.76601 & 99.18 & 26.17 & 0.85112 & 94.00 & 45.85 \\
D & 8217.00 & 0.93712 & 117.39 & 30.97 & 1.04125 & 100.33 & 48.94 \\
E & 10467.60 & 1.60040 & 149.54 & 39.46 & 1.77822 & 112.33 & 54.80 \\
F & 11025.33 & 1.75556 & 157.50 & 41.56 & 1.95062 & 116.67 & 56.91 \\
G & 13177.23 & 2.33828 & 188.25 & 49.67 & 2.59415 & 125.00 & 60.98 \\
H & 14049.36 & 2.47957 & 200.71 & 52.96 & 2.73285 & 140.00 & 68.29 \\
I & 12798.70 & 2.06707 & 182.84 & 48.24 & 2.29674 & 122.67 & 59.84 \\
AISI 1020 & - & - & 379.00 & - & - & 205.00 & - \\
AISI 301 & - & - & 520.00 & - & - & 206.00 & - \\
\hline
\end{tabular}

\section{Charpy Testing}

Each specimen was tested twice for the Charpy test, and the Charpy impact energy was recorded as shown in Table 5. Joint $\mathrm{H}$ exhibited the highest Charpy impact energy of 46.0J. Joint A exhibited the lowest Charpy impact energy of 31.0J. The Charpy impact energy for AISI 1020 carbon steel was 104J, and for AISI 301 stainless steel, was 120J. The highest joint efficiency was $44.23 \%$ for Joint H compare to AISI 1020 carbon steel base metal. The lowest joint efficiency was for Joint A with a numeric value of $29.81 \%$ compare to AISI 1020 carbon steel base metal. As can be seen from Table 6, the Charpy impact energy for all joints was less than 50\% compared to that for AISI 1020 carbon steel base metal. 
Table 5. Charpy test results (Charpy impact energy).

\begin{tabular}{cccc}
\hline \multirow{2}{*}{ Experiment Order. } & \multicolumn{3}{c}{ Charpy impact energy [J] } \\
\cline { 2 - 4 } & 1 & 2 & AVE \\
\hline A & 30.0 & 32.0 & 31.0 \\
B & 31.0 & 33.0 & 32.0 \\
C & 35.0 & 35.0 & 35.0 \\
D & 38.0 & 36.0 & 37.0 \\
E & 39.0 & 41.0 & 40.0 \\
F & 40.0 & 42.0 & 41.0 \\
G & 43.0 & 42.0 & 42.5 \\
H & 45.0 & 47.0 & 46.0 \\
I & 38.0 & 42.0 & 40.0 \\
\hline
\end{tabular}

\section{Analysis using the Taguchi Method}

\section{S/N Ratio}

The results of the tensile and Charpy tests were used in the Taguchi analysis. Table 6 shows the input parameters and the values of output or responses (tensile strength and Charpy impact energy). The signal-to-noise ratio (S/N ratio) was calculated based on the results from the tensile tests (tensile strength) and the Charpy tests (impact energies) using Eq. (1) given below. After calculation, the value was tabulated in Table 7.

$$
S / N=-10 \times \log \left[S\left(1 / Y^{2}\right)\right] \times(1 / n)
$$

Table 6. Inputs (variable parameters) and responses (tensile strength and Charpy impact energy).

\begin{tabular}{ccccccc}
\hline $\begin{array}{c}\text { Experiment } \\
\text { No. }\end{array}$ & $\begin{array}{c}\text { Current } \\
(\mathrm{kA})\end{array}$ & $\begin{array}{c}\text { Welding } \\
\text { Squeeze } \\
\text { Time } \\
\text { (cycle) }\end{array}$ & $\begin{array}{c}\text { Welding } \\
\text { pressure } \\
(\mathrm{MPa})\end{array}$ & $\begin{array}{c}\text { Tensile } \\
\text { Strength } \\
(\mathrm{MPa})\end{array}$ & $\begin{array}{c}\text { Charpy } \\
\text { Impact } \\
\text { Energy }(\mathrm{J})\end{array}$ & $\begin{array}{c}\text { Joint efficiency } \\
\text { in \% of Impact } \\
\text { Energy of AISI } \\
1020\end{array}$ \\
\hline A & 3.0 & 2.5 & 0.21 & 66.43 & 31.00 & 29.81 \\
B & 3.0 & 3.0 & 0.24 & 86.47 & 32.00 & 30.77 \\
C & 3.0 & 3.5 & 0.28 & 99.18 & 35.00 & 33.65 \\
D & 4.0 & 2.5 & 0.24 & 117.39 & 37.00 & 35.58 \\
E & 4.0 & 3.0 & 0.28 & 149.54 & 40.00 & 38.46 \\
F & 4.0 & 3.5 & 0.21 & 157.50 & 41.00 & 39.42 \\
G & 5.0 & 2.5 & 0.28 & 188.25 & 42.50 & 40.87 \\
H & 5.0 & 3.0 & 0.21 & 200.71 & 46.00 & 44.23 \\
I & 5.0 & 3.5 & 0.24 & 182.84 & 40.00 & 38.46 \\
AISI1020 & - & - & - & - & 104.00 & - \\
AISI301 & - & - & - & - & 120.00 & - \\
\hline
\end{tabular}


Table 7. S/N Ratio of tensile strength and Charpy impact energies.

\begin{tabular}{ccccc}
\hline $\begin{array}{c}\text { Experiment } \\
\text { No. }\end{array}$ & $\begin{array}{c}\text { Tensile } \\
\text { Strength }(\mathrm{MPa}) \\
\text { (average) }\end{array}$ & $\begin{array}{c}\text { S/N ratio for } \\
\text { Tensile } \\
\text { Strength in db }\end{array}$ & $\begin{array}{c}\text { Charpy Impact } \\
\text { Energy (J) } \\
\text { (average) }\end{array}$ & $\begin{array}{c}\text { S/N ratio for Charpy } \\
\text { Energy in db }\end{array}$ \\
\hline B & 66.43 & 15.6391 & 32.0 & 30.1029 \\
C & 86.47 & 16.8307 & 35.0 & 30.8813 \\
D & 99.18 & 18.2942 & 37.0 & 31.3640 \\
E & 117.39 & 20.3969 & 40.0 & 32.0411 \\
F & 149.54 & 20.8478 & 41.0 & 32.2556 \\
G & 157.50 & 22.3964 & 42.5 & 32.5677 \\
H & 188.25 & 22.9531 & 46.0 & 33.2551 \\
I & 200.71 & 22.1433 & 40.0 & 32.0411 \\
\hline
\end{tabular}

\section{Analysis of Variance}

The results of the ANOVA are shown in Tables 8 and 9. The $P$ values in Table 8 for the three parameters confirm that the "Welding Current" is the most significant and "Welding Pressure" is the least significant parameter for influencing tensile strength and Charpy impact energy. From Table 9, the "Welding Current" had the highest F value (91.28). The second highest F value was for "Welding Squeeze Time", (5.19) and the lowest F value was observed for the "Welding Pressure", (2.45). The highest P-value of 0.290 was observed for the "Welding Pressure". The "Welding Squeeze Time" has second highest $\mathrm{P}$ value of 0.161 , and the lowest $\mathrm{P}$ was for "Welding Current" which was 0.011. From this value of F-test and P, it can be concluded that "Welding Current" is the most significant, and "Welding Pressure" is the least significant, parameter for influencing tensile strength and Charpy impact energy.

Table 8. Estimated model coefficients for means.

\begin{tabular}{lcccc}
\hline \multicolumn{1}{c}{ Term } & Coefficient & $\begin{array}{c}\text { Sum of Error } \\
\text { Coefficient }\end{array}$ & T (T-value) & P (P-value) \\
\hline Constant & 4873.65 & 113.0 & 43.143 & 0.001 \\
Current & -1916.32 & 159.8 & -11.995 & 0.007 \\
Current & 97.67 & 159.8 & 0.611 & 0.603 \\
Welding Squeeze & -514.48 & 159.8 & -3.220 & 0.084 \\
Time & & & & \\
Welding Squeeze & 240.98 & 159.8 & 1.508 & 0.270 \\
Time & 100.18 & 159.8 & 0.627 & 0.595 \\
Welding pressure & -344.07 & 159.8 & -2.154 & 0.164 \\
Welding pressure & & & & \\
\hline
\end{tabular}

A ranking list for the variable parameters, namely the "Welding Current", "Welding Squeeze Time" and "Welding Pressure" that affected the tensile strength and the Charpy impact energy is shown in Table 10. Welding current was ranked at the top, followed by welding pressure and welding squeeze time. 
Table 9. Analysis of variance for means.

\begin{tabular}{|c|c|c|c|c|c|c|}
\hline Source & $\begin{array}{l}\text { Degree of } \\
\text { Freedom }\end{array}$ & $\begin{array}{l}\text { Sequence } \\
\text { Sum of } \\
\text { Square }\end{array}$ & $\begin{array}{l}\text { Adjusted Sum } \\
\text { of Square }\end{array}$ & $\begin{array}{l}\text { Adjusted Mean } \\
\text { of Square }\end{array}$ & $\begin{array}{l}(\mathrm{F}- \\
\text { test })\end{array}$ & $\begin{array}{l}\text { (P- } \\
\text { value) }\end{array}$ \\
\hline Welding Current (A) & 2 & 20967931 & 20967931 & 10483965 & 91.28 & 0.011 \\
\hline $\begin{array}{l}\text { Welding Squeeze } \\
\text { Time (B) }\end{array}$ & 2 & 1192688 & 1192688 & 596344 & 5.19 & 0.161 \\
\hline $\begin{array}{l}\text { Welding pressure } \\
\text { (C) }\end{array}$ & 2 & 563693 & 563693 & 281847 & 2.45 & 0.290 \\
\hline Residual Error & 2 & 229699 & 229699 & 114849 & & \\
\hline Total & 8 & 22954010 & & & & \\
\hline
\end{tabular}

Table 10. Response table for $\mathrm{S} / \mathrm{N}$ ratios.

\begin{tabular}{cccc}
\hline Level & Welding Current & Welding Squeeze Time & Welding Pressure \\
\hline 1 & 33.28 & 34.26 & 34.79 \\
2 & 34.90 & 34.81 & 34.18 \\
3 & 35.63 & 34.74 & 38.84 \\
Delta & 2.35 & 0.55 & 0.66 \\
Rank & 1 & 3 & 2 \\
\hline
\end{tabular}

\section{Predicting the Optimum Parameters}

Prediction of the optimum parameters was made using the response table for the $\mathrm{S} / \mathrm{N}$ ratios, as shown in Table 10. The $\mathrm{S} / \mathrm{N}$ ratio used in this analysis was defined such that the "Larger the Better". The graph of the "Main Effects Plot for Means and S/N Ratio" is shown in Figure 3. These graphs show the parameters being optimized. The set of optimum parameters are: Welding Current $=5.0 \mathrm{kA}$, Welding Squeeze Time $=3.0$ cycles, and Welding Pressure $=40$ psi. With the optimized parameters, another two sets of experiments were performed both for tensile and Charpy impact testing to find the tensile strength and Charpy impact energy of the joints. The results were investigated and analyzed to determine whether the experimental results validated the optimized parameter settings discussed in the "Macro Structural Analysis" section. According to the main effects plot from Fig. 3(a) and 3(b), it is obvious that welding current is the most influential, welding pressure is the second most influential and welding squeeze time is the least influential parameter affecting the tensile strength and Charpy impact energy of the joints. Figure 3 also reveals that the level of factors with the highest $\mathrm{S} / \mathrm{N}$ ratio is the optimal level. According to this, the optimal configuration of parameters for tensile strength and Charpy impact energy are, "Welding Current" $=5 \mathrm{kA}$; "Welding Pressure"=40psi and "Welding Squeeze Time"= 3 cycles (Ambrogio, Gagliardi, \& Filice, 2013) 


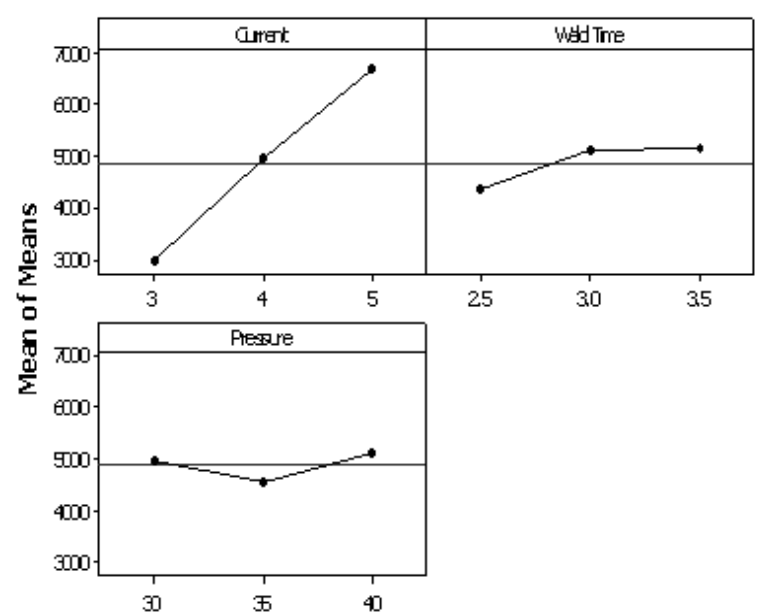

(a)

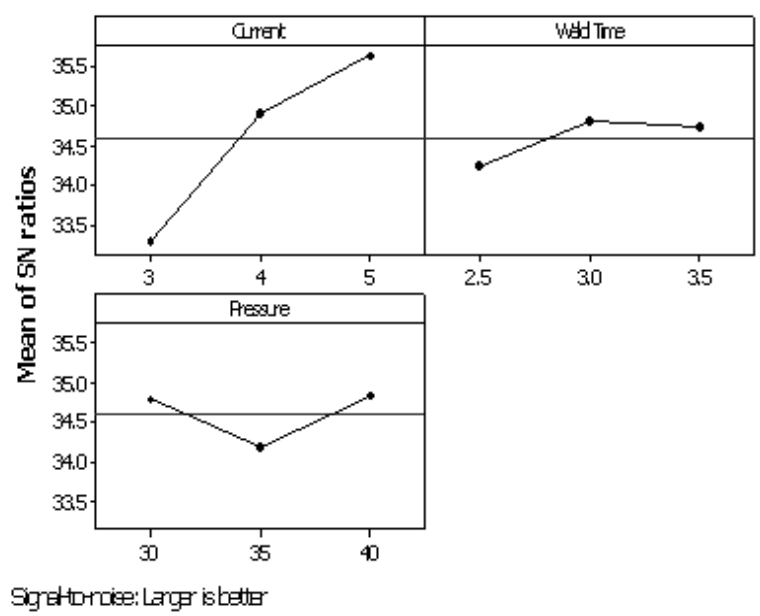

(b)

Figure 3: (a) Main effects plot for the means, (b) Main effects plot for S/N ratios.

\section{Regression Analysis}

A regression analysis was conducted to obtain the regression model for tensile strength and the Charpy impact energy. Regression analysis was used to generate a model to describe the relationships between the predictors (parameters) and the response (results from the tensile and Charpy tests). This analysis was also used to predict new observations. The regression models for tensile strength and Charpy impact energy are shown in Eq. (2) and Eq. (3) respectively.

$$
\begin{aligned}
& \text { Tensile Strength }=10939+3730 \times \text { Welding Current } \\
& +1574 \times \text { Welding Squeeze Time }+28.8 \times \text { WeldingPr essure } \\
& \text { Charpy Impact energy }=13.0+5.08 \times \text { Welding Current } \\
& +1.83 \times \text { Welding Squeeze Time }-0.017 \times \text { Welding Pressure }
\end{aligned}
$$

Based on regression analysis, the comparison between the experiment values and the predicted values for tensile strength and Charpy impact energy are shown in Table 11. The calculated values from the models are slightly higher than the experimental results, however, based on the comparison between the predicted mean values of the tensile strength and the Charpy impact energy from the regression models, and the experimental results (based on the optimum parameter), the experimental values are validated. Figure 4 shows the relationship between the actual and predicted values for the tensile strength and Charpy impact energy. From Fig. 4 it is obvious that the developed models are adequate. The residuals in the prediction of each response are negligible because the residuals tend to be close to the diagonal line. The regression lines for both tensile strength and Charpy impact energy in Figure 4 show that the slope is very high, which means that the regression model for tensile strength and Charpy impact energy are valid because of the closeness between the experimental values and the predicted values from the regression models. 
Table 11. Comparisons between experimental and prediction results.

\begin{tabular}{ccccc}
\hline Specimen & $\begin{array}{c}\text { Tensile } \\
\text { Strength (MPa) } \\
\text { (Experimental) }\end{array}$ & $\begin{array}{c}\text { Tensile } \\
\text { Strength (MPa) } \\
\text { (Predicted) }\end{array}$ & $\begin{array}{c}\text { Charpy Impact } \\
\text { Energy, (J) } \\
\text { (Experimental) }\end{array}$ & $\begin{array}{c}\text { Charpy Impact } \\
\text { Energy, }(\mathrm{J}) \\
\text { (Predicted from } \\
\text { Taguchi analysis) }\end{array}$ \\
\hline A & 66.43 & 72.14 & 31.0 & 32.305 \\
B & 86.47 & 85.44 & 32.0 & 33.135 \\
C & 99.18 & 98.74 & 35.0 & 33.965 \\
D & 117.39 & 127.49 & 37.0 & 37.300 \\
E & 149.54 & 148.00 & 40.0 & 38.130 \\
F & 157.50 & 147.91 & 41.0 & 39.215 \\
G & 188.25 & 182.83 & 42.5 & 42.295 \\
H & 200.71 & 189.96 & 46.0 & 43.380 \\
I & 182.84 & 203.26 & 40.0 & 44.210 \\
Optimum & 212.33 & 194.07 & 46.0 & 43.210 \\
\hline
\end{tabular}

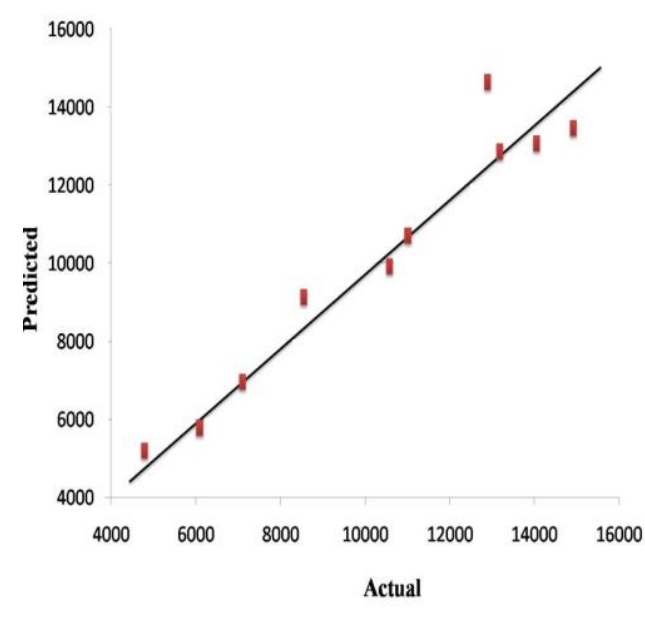

(a)

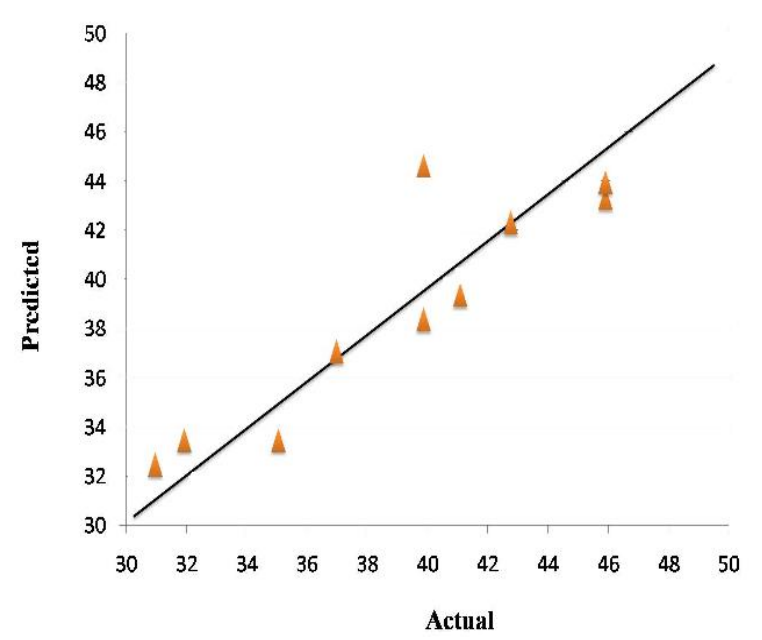

(b)

Figure 4: (a) Relationship between the predicted and the experimental values of tensile strength (MPa); (b) Relationship between the predicted and the experimental values of Charpy impact energy $(\mathrm{J})$

\section{Surface and contour plot}

Surface and contour plots were also obtained from the analysis, and used to show the relationship between the parameters and the responses, that is which parameter contributed the most to the responses. Fig. 5(a) and 5(b) show the surface plots of the Charpy impact energy and the tensile strength versus the first and second most influential parameters (welding pressure and welding current). Fig. 5(c) and 5(d) show the contour plots of Charpy impact energy and the tensile strength versus welding pressure and current. 


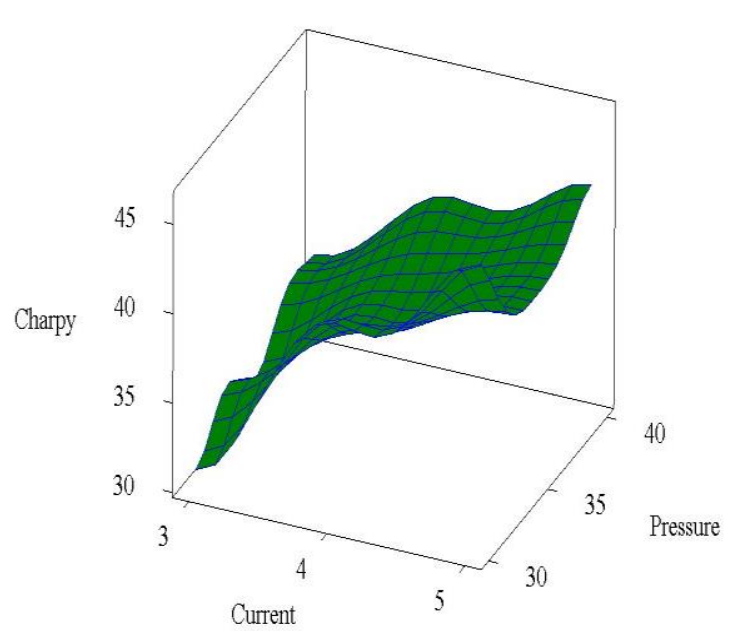

(a)

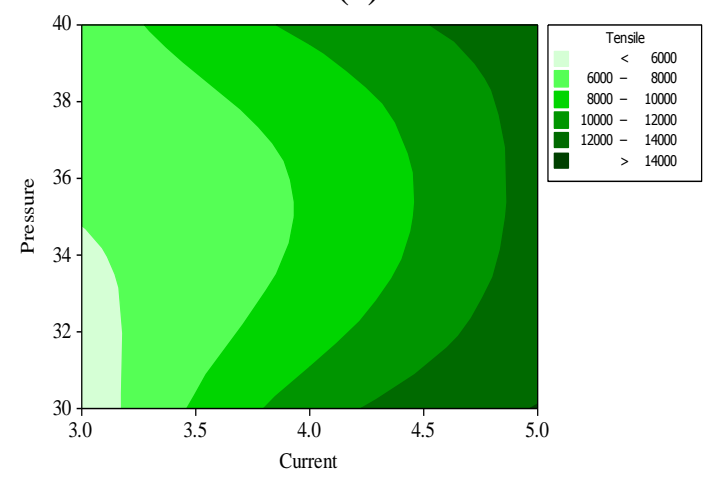

(c)

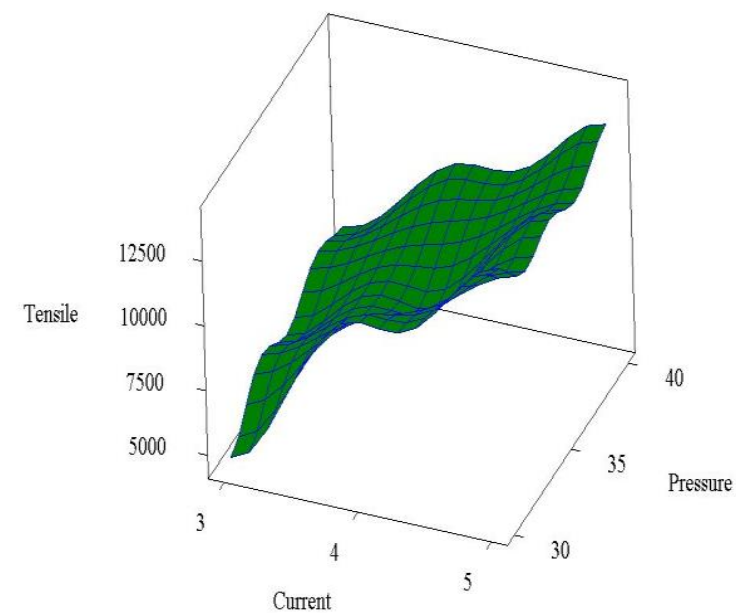

(b)

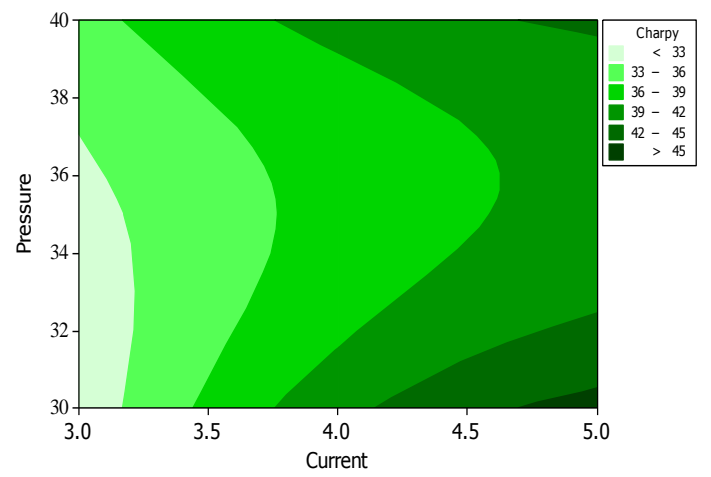

(d)

Figure 5: (a) Surface plot of Charpy impact energy vs. welding pressure and welding current, (b) Surface plot of tensile strength vs. welding pressure and welding current, (c) Contour plot of tensile strength vs. welding pressure and welding current, (d) Contour plot of the Charpy impact energy vs. welding pressure and welding current.

In Figures 5(c) and 5(d), the lighter green shades cover the area where less tensile strength and Charpy impact energy will be acquired, however, the darker green regions cover the area where the highest value of the tensile strength and the Charpy impact energy can be achieved. When the parameter values increase, the values of the tensile strength and Charpy impact energies also increase, to specific limits. From these results, it can be concluded that at "Welding Current", 5kA and "Welding Pressure", 40psi tensile strength and Charpy impact energy will reach maximum values (Baradeswaran, Elayaperumal, \& Issac, 2013). The surface and contour plot in Figure 5 also proves the validity of the optimized parameter settings for tensile strength and Charpy impact energy. This plot also proves that "Welding Current" and "Welding Pressure" are the most significant parameters for influencing tensile strength and Charpy impact energy, which has been demonstrated already in Table 8 and Table 9.

\section{Macro Structural Analysis}

The weld nugget's width and depth were investigated for Joint A, Joint H, and joints with optimized parameters as shown Fig. 6 (a), 6(b) and 6 (c) respectively. It is clear from the macro structural illustration of Figure 6(a) for Joint A that the difference between macrostructure at nugget, and around the nugget area is not distinguishable. 
This means that there was not enough melting or enough bonding in this joint, which is why the tensile strength and Charpy impact energy values were lowest for this joint. Figure 6(b) shows that there was good melting and better penetration depth. This proved that there was better bonding between the two alloy sheets. The macro structure between the nugget and other area is clearly distinguishable and the weld nugget is clearly visible, therefore, the tensile strength and Charpy impact energy for this joint was higher compared to Joint A. Figure 6(c) shows the weld joint macrostructure at optimized parameter settings which clearly demonstrates even better melting and penetration depth. The penetration is highest and the joint seems to have better bonding. The tensile strength and Charpy impact energy was highest for this joint with optimized parameter settings. There were no IMCs seen at any of the joints. Figure 7 shows the plot for weld nugget width, and penetration depth for all joints (including the joint with optimum parameters setting). The joint with optimum conditions had the highest weld width and penetration depth of $9.316 \mathrm{~mm}$ and $3.145 \mathrm{~mm}$ respectively. The second highest was for joint $\mathrm{H}$ (weld width, $8.62 \mathrm{~mm}$ and penetration depth, $2.853 \mathrm{~mm}$ ). The lowest weld width and penetration depth was for Joint A, which were $2.349 \mathrm{~mm}$ and $0.587 \mathrm{~mm}$ respectively. The validation test for the joint with optimum conditions obtain highest tensile strength (212.33MPa) and Charpy impact energy (46J) (showed in Table 11) which has validated the optimization model.

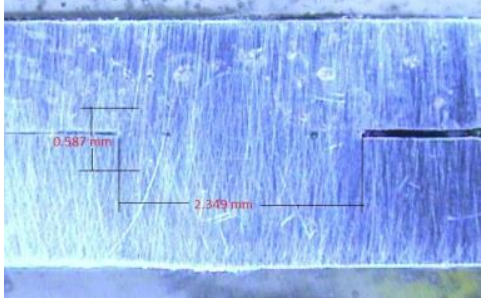

(a)

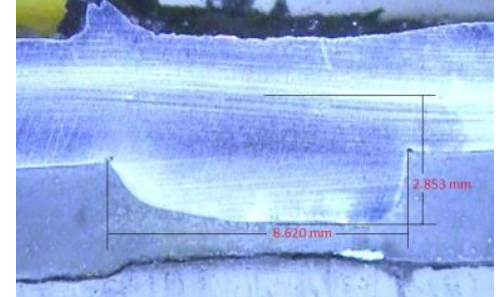

(b)

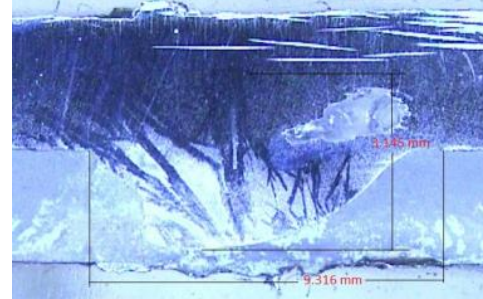

(c)

Figure 6: (a) Macrostructure of weld joint A (weld width $=2.349 \mathrm{~mm}$ and penetration depth $=0.587 \mathrm{~mm}$ ), (b) Macrostructure of weld joint $\mathrm{H}$ (weld width $=8.620 \mathrm{~mm}$ and penetration depth $=2.853 \mathrm{~mm}$ ) and (c) Macrostructure of the joint at optimized welding condition (Weld width $=9.316 \mathrm{~mm}$ and penetration depth $=3.145 \mathrm{~mm}$ ).

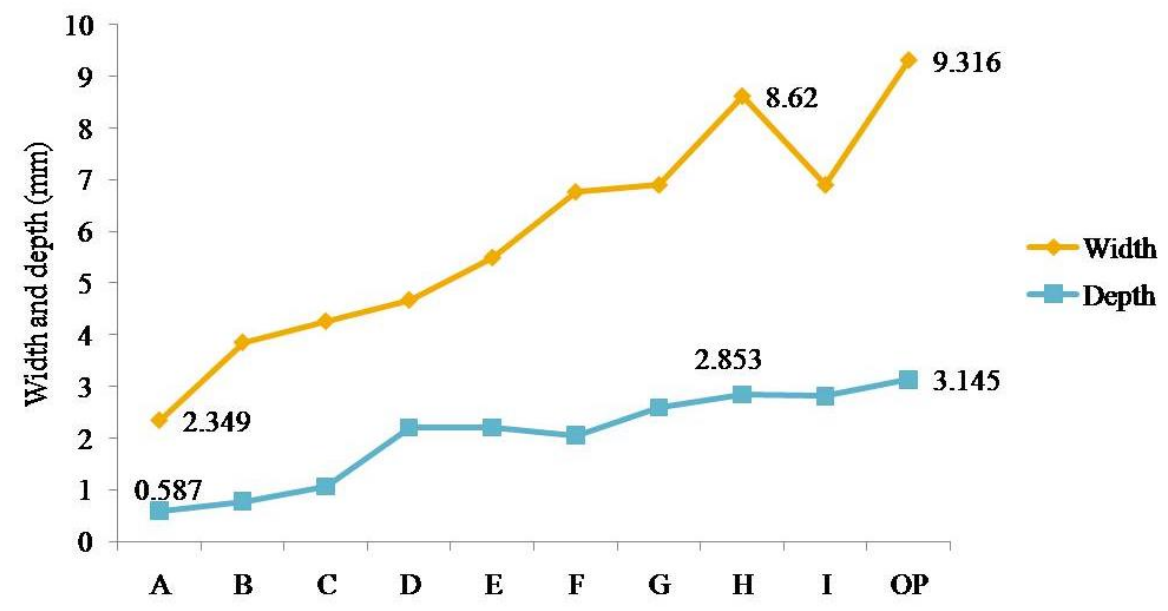

Figure 7. Weld nugget dimension (W, width in $\mathrm{mm}$ and $\mathrm{D}$, depth in $\mathrm{mm}$ ). 


\section{CONCLUSIONS}

i) Weld Joint $\mathrm{H}$ (5.0kA, 3.0 cycles, and 30psi) produced a higher tensile strength (200.71MPa) and Charpy impact energy (46.0J) compared to the other joints. The optimum weld condition, OP (5.0kA, 3.0 cycle and 40psi) achieved highest tensile strength (212.33MPa) and Charpy impact energy (46.0J).

ii) The higher tensile strength and Charpy impact energy were due to an increase in the width and depth of the weld nugget. The weld nugget dimensions (weld width and penetration depth) for optimum weld condition (OP), were highest when comparing all joints. No IMCs were visible at any joints.

iii) The Taguchi optimization analysis revealed that the best combination of parameters for highest tensile strength and Charpy impact energy is: welding current, 5.0kA; welding squeeze time, 3.0 cycles; and welding pressure, 40psi. The descending order of parameters that has most influence on the response in this research was Welding Current> Welding Pressure> Welding Squeeze Time. The predicted values for tensile strength and Charpy impact energy by Taguchi analysis were in agreement with the values from the experiments.

\section{ACKNOWLEDGEMENTS}

The authors would like to thank the Faculty of Mechanical Engineering, University of Malaysia Pahang for the material and laboratory facilities used for successful completion of this research work.

\section{REFERENCES}

Alenius, M., Pohjanne, P., Somervuori, M., \& Hänninen, H. (2006). Exploring the mechanical properties of spot welded dissimilar joints for stainless and galvanized steels. Welding Journal, 305-312.

Ambrogio, G., Gagliardi, F., \& Filice, L. (2013). Robust design of incremental sheet forming by taguchi's method. Procedia CIRP, 12(0), 270-275.

Aslanlar, S., Ogur, A., Ozsarac, U., \& Ilhan, E. (2008). Welding time effect on mechanical properties of automotive sheets in electrical resistance spot welding. Materials \& Design, 29(7), 1427-1431.

Baradeswaran, A., Elayaperumal, A., \& Issac, R. F. (2013). A statistical analysis of optimization of wear behaviour of al- al2o3 composites using taguchi technique. Procedia Engineering, 64(0), 973-982.

Charde, N. (2012a). Characterization of spot weld growth on dissimilar joints with different thicknesses. Journal of Mechanical Engineering and Sciences, 2, 172180.

Charde, N. (2012b). Effects of electrode deformation of resistance spot welding on 304 austenitic stainless steel weld geometry. Journal of Mechanical Engineering and Sciences, 3, 261-270.

Farhad, K., \& Mehdi, H. (2010). Modeling and optimization of mag welding for gas pipelines using regression analysis and simulated annealing algorithm. Journal of Scientific and Industrial Research, 69, 259-265.

Fonseca, N., Casanova, J., \& Valdés, M. (2011). Influence of the stop/start system on co2 emissions of a diesel vehicle in urban traffic. Transportation Research Part D: Transport and Environment, 16(2), 194-200. 
Hamidinejad, S., Kolahan, F., \& Kokabi, A. (2012). The modeling and process analysis of resistance spot welding on galvanized steel sheets used in car body manufacturing. Materials \& Design, 34, 759-767.

Hernandez, B. V., Kuntz, M., Khan, M., \& Zhou, Y. (2008). Influence of microstructure and weld size on the mechanical behaviour of dissimilar ahss resistance spot welds. Science and Technology of Welding \& Joining, 13(8), 769-776.

Imaizumi, S. (1984). Welding of aluminum to dissimilar metals. Journal of Light Metal Welding and Construction, 22(9), 408-419.

Kolarik, L., Sahul, M., Kolarikova, M. M., Sahul, M., Turna, M., \& Felix, M. (2012). Resistance spot welding of dissimilar steels. Acta Polytechnica, 52(3), 43-47.

Luo, Y., Liu, J., Xu, H., Xiong, C., \& Liu, L. (2009). Regression modeling and process analysis of resistance spot welding on galvanized steel sheet. Materials \& Design, 30(7), 2547-2555.

Marashi, P., Pouranvari, M., Amirabdollahian, S., Abedi, A., \& Goodarzi, M. (2008). Microstructure and failure behavior of dissimilar resistance spot welds between low carbon galvanized and austenitic stainless steels. Materials Science and Engineering: A, 480(1), 175-180.

Martín, Ó., López, M., \& Martín, F. (2007). Artificial neural networks for quality control by ultrasonic testing in resistance spot welding. Journal of Materials Processing Technology, 183(2), 226-233.

Rafiqul, M. I., Ishak, M., \& Rahman, M. M. (2012). Effects of heat input on mechanical properties of metal inert gas welded $1.6 \mathrm{~mm}$ thick galvanized steel sheet. IOP Conference Series: Materials Science and Engineering, 36(1).

Rahman, M. M., Arrifin, A. K., Nor, M. J. M., \& Abdullah, S. (2008). Fatigue analysis of spot-welded joint for automative structures. SDHM Structural Durability and Health Monitoring, 4(3), 173-180.

Rahman, M. M., Rosli, A. B., Noor, M. M., Sani, M. S. M., \& Julie, J. M. (2009). Effects of spot diameter and sheets thickness on fatigue life of spot welded structure based on fea approach. American Journal of Applied Sciences, 6(1), 137-142.

Serope, K., \& Steven, S. (2000). Manufacturing engineering and technology 5th edition in si unit: Prentice Hall.

Shah, L. H., Akhtar, Z., \& Ishak, M. (2013). Investigation of aluminum-stainless steel dissimilar weld quality using different filler metals. International Journal of Automotive and Mechanical Engineering, 8, 1121-1131. 